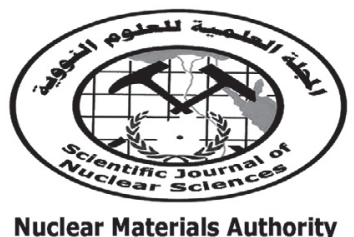

ISSN 2314-5609

Nuclear Sciences Scientific Journal vol. 1, p 1-22

\begin{abstract}
P.O.Box 530 Maadi, Cairo, Egypt
\end{abstract}
\title{
GEOCHEMICAL CHARACTERISTICS OF SOME PERALUMINOUS YOUNGER GRANITE MASSES, EASTERN DESERT, EGYPT
}

\author{
MASOUD S. MASOUD \\ Nuclear Materials Authority, P. O. Box 530, El-Maadi, Cairo, Egypt
}

\begin{abstract}
$\overline{\text { ABSTRACT }}$
Sixteen representative samples of younger granites from Gabal El Mueilha, Gabal Harhagite and Gabal Qash Amir in the central and south Eastern Desert of Egypt were analyzed for major, trace and rare earth elements. Petrographical and geochemical studies revealed that, Gabal Harhagite is monzogranite, while Gabal El Mueilha and Gabal Qash Amir are syeno- to alkali feldspar granites. They are classified as I-type peraluminous granite $(\mathrm{A} / \mathrm{CNK}=1.46-1.67)$, $\mathrm{P}$-poor $\left(\mathrm{P}_{2} \mathrm{O}_{5}<0.07 \mathrm{wt} \%\right)$ and $\mathrm{Na}_{2} \mathrm{O}$-rich $(\leq 7.08 \mathrm{wt} \%)$ exhibiting differences in their REE contents. Gabal Qash Amir and Gabal El Mueilha are within- plate granite whereas Gabal Harhagite is volcanic arc granite.

Peraluminous granite are good source for the uranium, rare metals $(\mathrm{Nb}-\mathrm{Ta}, \mathrm{Be}, \mathrm{W})$ and rare earths ( $\mathrm{La}, \mathrm{Lu}, \mathrm{Nd}, \mathrm{Dy}, \mathrm{Y})$ mineralizations are examined for Gabal El Mueilha, Gabal Harhagite and Gabal Qash Amir younger granites. These granites show rare metal contents $(\mathrm{Nb}=81, \mathrm{Yb}=20, \mathrm{U}=14, \mathrm{Ta}=25 \mathrm{ppm})$ and in some rare earth elements $(\mathrm{La}=12, \mathrm{Lu}=3, \mathrm{Y}=102, \mathrm{Nd}=17$, Dy $=12 \mathrm{ppm})$. Chondrite-normalized REE diagram shows that Gabal El Mueilha granite samples display strong HREE enrichment relative to LREE which show flat pattern with moderate to strong negative Eu anomalies. On the otherhand Gabal Harhagite and Gabal Qash Amir granite show high enrichment in LREE compared with HREE which desplay slightly falling slope with strong to low negative Eu anomalies. Field radiometric measurements revealed that the radioactivity level up to $34 \mathrm{ppm}(\mathrm{eU})$. at Gabal El Mueilha granite , at Gabal Harhagite granite reach up to $9.5 \mathrm{ppm}(\mathrm{eU})$, while at Gabal Qash Amir granite reach up to $47 \mathrm{ppm}(\mathrm{eU})$.This type of granites assumed to be a specific type for tin and tungestin mineralizations.
\end{abstract}




\section{الخواص الجيوكيميائية لبعض الجرانيتات الحليثة العالية الالومينا ــ الصحراء الثرقية ـ مصر}

$$
\text { مسعود صلاح مسعود }
$$

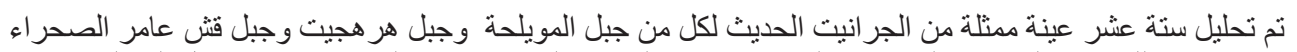

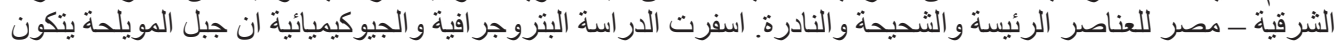

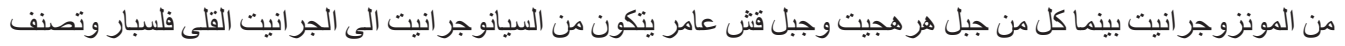

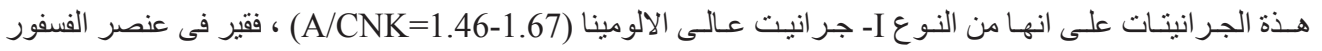
غنى فى عنصر اكسيد الصوديوم $\quad\left(\mathrm{P}_{2} \mathrm{O}_{5}<0.07 \mathrm{wt} \%\right)$ العناصر الارضيةً النادرة. اظهرت هذة الدراسات ايضا ان كل من جبل المويلحة وجيل قُّن عامر ينتموا الى بيئة قارية بينما جبل هر هجيت ينتمى الى بيئة اقو اس جزربر كانية.

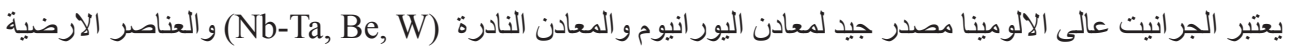

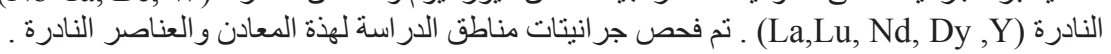

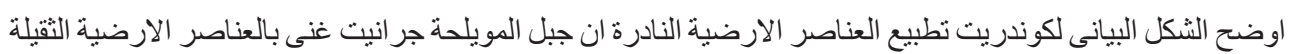

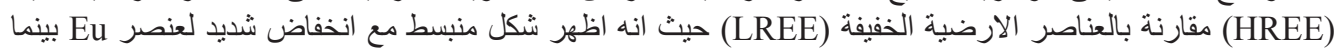

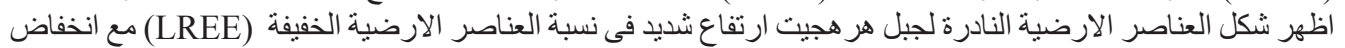

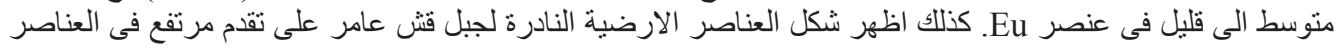

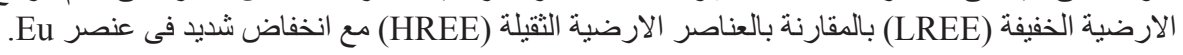

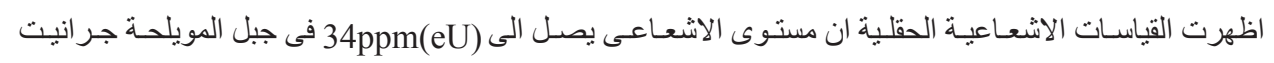
9 9.5ppm(eU) فى جبل هر هجيت جرانيت بينما 47ppm (eU) فى جبل قش عامر جرانيت. 